\title{
PENGARUH PERILAKU TENAGA KERJA DAN \\ TINGKAT PENDIDIKAN TERHADAP KESELAMATAN KERJA KONSTRUKSI DI SUMENEP
}

\author{
Ach. Desmantri Rahmanto ${ }^{1}$, Ahmad Suwandi ${ }^{2}$ \\ 1) Prodi Teknik Sipil, Fakultas Teknik, Universitas Wiraraja Sumenep, ach.desmantri92@gmail.com \\ 2) Prodi Teknik Sipil, Fakultas Teknik, Universitas Wiraraja Sumenep
}

\begin{abstract}
ABSTRAK
Di proyek konstruksi setiap kegiatan mempunyai tingkat resiko keselamatan kerja. Perilaku tenaga kerja dan tingkat pendidikan mempunyai potensi mempengaruhi keselamatan kerja.Tujuannya yaitu untuk mengetahui tingkat pendidikan (X2) yang berpengaruh pada perilaku tenaga kerja (X1), dengan keselamatan kerja (Y). Kesehatan tenaga kerja perlu diperhatikan. Perlindungan kesehatan tenaga kerja ini akan meningkatkan produktifitas dan efisiensi kerja.

Penelitian ini menggunakan metode survey dengan data yang dibutuhkan dalam penelitian ini meliputi dua jenis data yaitu data primer dan data sekunder, baik bersifat kuantitatif maupun kualitatif. Analisis yang digunakan dengan menggunakan analisis regresi linier berganda. Responden yang dijadikan pengukuran adalah para tukang, pekerja,kepala tukang dan mandor. Penyebaran kuisioner di 5 lokasi proyek.

Berdasarkan hasil analisa, perilaku tenaga kerja berpengaruh secara signifikan terhadap keselamatan kerja $(\mathrm{R}=0,668)$. Sedangkan pada tingkat pendidikan tidak mempengaruhi secara signifikan terhadap keselamatan kerja $(\mathrm{R}=0,062)$. Upaya mencegah kecelakaan pada pekerjaankonstruksi dimulai dengan rencana kerja yangaman dan pikiran yang sehat untuk pedoman setiap kegiatan yang akan dikerjaan. Oleh sebab itu para pekerja pakailah perlengkapan yangpemerintah telah mengeluarkan suatu peraturan tentang keselamatan kerja khusus untuk sektor konstruksi.
\end{abstract}

Kata Kunci : Perilaku Tenaga Kerja dan tingkat pendidikan.

\section{PENDAHULUAN}

\subsection{Latar Belakang}

Tenaga kerja merupakan sumber daya manusia yang penting dalam pembangunan proyek. Oleh karena itu, kesehatan tenaga kerja perlu diperhatikan. Perlindungan kesehatan tenaga kerja ini akan meningkatkan produktifitas dan efisiensi kerja.

Akhir-akhir ini kecelakaan kerja yang terjadi pada proyek konstruksi mungkin sudah tidak di perhitungkan lagi. Hal ini didasarkan pada penelitian sebelumnya oleh (Iqbal Alfaris,2013) menyatakan bahwa bagi instansi, perilaku tenaga kerja dan tingkat pendidikan bukanlah salah satu faktor yang mempengaruhi kecelakaan kerja, tetapi hanyalah sebagian dari pengaruh kecelakaan kerja. Maka oleh sebab itu, bagi semua instansi yang berhubungan dengan proyek kontruksi lebih berhati-hati dan lebih waspada untuk mengurangi dan menghindari kecelakaan kerja.

\subsection{Perumusan Masalah}

Permasalahan dalam penelitian ini adalah:

1. Apakah perilaku tenaga kerja (X1) berpengaruh dengan keselamatan kerja (Y)?

2. Apakah tingkat pendidikan (X2) berpengaruh pada perilaku tenaga kerja (X1), dengan keselamatan kerja $(\mathrm{Y})$ ? 


\subsection{Tujuan}

2. Untuk mengetahui perilaku tenaga kerja (X1) berpengaruh dengan keselamatan $\operatorname{kerja}(\mathrm{Y})$.

3. Untuk mengetahui tingkat pendidikan (X2) yang berpengaruh pada perilaku tenaga kerja (X1), dengan keselamatan kerja (Y).

\subsection{Manfaat}

Manfaat penelitian ini adalah :

Beberapa manfaat secara praktis dari penelitian ini, yaitu sebagai berikut :

1. Memberikan pemikiran serta membantu memecahkan suatu permasalahan yang sering terjadi pada proyek konstruksi tentang kecelakaan kerja.

2. Menambah pengetahuan dan wawasan mengenai permasalahan yang sering terjadi pada proyek konstruksi yaitu tentang kesehatan kerja, serta menghindari darikecelakaan kerja.

3. Untuk perkembangan ilmu mengenai konstruksi khususnya dalam bidang kesehatan dan keselamatan kerja.

\section{HASIL DAN PEMBAHASAN}

\subsection{Responden Berdasarkan Tingkat Pendidikan (X2)}

Dari hasil kuisioner yang telah didapat, diperoleh gambaran tentang pendidikan responden dan dapat dilihat pada tabel

Tabel 2.1 Responden Berdasarkan Tingkat Pendidikan

\begin{tabular}{|c|c|c|}
\hline $\begin{array}{c}\text { Tingkat } \\
\text { Pendidikan }\end{array}$ & $\begin{array}{c}\text { Jumlah } \\
\text { Responden }\end{array}$ & Prosentase \\
\hline SD/MI & 19 & $31,66 \%$ \\
\hline SMP/MTs & 22 & $36,67 \%$ \\
\hline SMA/SMK/MA & 19 & $31,66 \%$ \\
\hline PT & 0 & $0 \%$ \\
\hline Total & 60 & 100 \\
\hline
\end{tabular}

Sumber : Hasil Analisis Data

\subsection{Uji Validitas}

Jika nilai corrected item-total correlation $>\mathrm{r}$ tabel $(\mathrm{r}=$ nilai table dengan cara membuka $\mathrm{r}$-tabel dengan melihat tingkat signifikansi 0,05 dan dengan jumlah data $\mathrm{n}=$ 60) maka item-item atau butir pertanyaan tersebut valid. Maka nilai $r$ tabel diperoleh nilai sebesar 0,254 .

Berdasarkan hasil pengujian validitasdapat disimpulkan bahwa masing-masing variable telah valid, karena nilai r-hitung berada dibawah $r$ - tabel

\subsection{Uji Reliabilitas}

Berikut adalah hasil pengujian reliabilitas dari bantuan program SPSS dan hasilreabilitas dapat dilihat pada tabel 
Tabel 2.2 Hasil Uji Reliabilitas

\begin{tabular}{|c|c|c|}
\hline & $\begin{array}{c}\text { Cronbach's } \\
\text { Alpha if Item } \\
\text { Deleted }\end{array}$ & Keterangan \\
\hline X1 & 0,527 & Reliabel \\
\hline X2 & 0,426 & Reliabel \\
\hline X3 & 0,500 & Reliabel \\
\hline X4 & 0,518 & Reliabel \\
\hline X5 & 0,654 & Reliabel \\
\hline X6 & 0,573 & Reliabel \\
\hline X7 & 0,576 & Reliabel \\
\hline X8 & 0,567 & Reliabel \\
\hline
\end{tabular}

Sumber : Hasil analisis Data SPSS

Berdasarkan tabel 2.2 diketahui bahwa besarnya Cronbach Alpha adalah 0,527 r tabel dengan jumlah data $(n)=60$, didapatkan nilai $r$ tabel sebesar 0,254 sedangkan besarnya Cronbach Alpha pada table 2.2

\subsection{Uji Normalitas}

Dalam pembahasan ini akan digunakan uji One Sample Kolmogorov-Smirnov dengan menggunakan taraf signifikansi 0,05. Data dinyatakan berdistribusi normal jika signifikansi lebih besar dari 5\%.untuk perilaku tenaga kerja sebesar 1,985; dan untuk tingkat pendidkan sebesar 1,629.

\subsection{Uji Multikolinearitas}

Dari hasil di atas dapat diketahui nilai variance inflation factor ( VIF ) kedua variabel yaitu perilaku dan tingkat pendidikan adalah 1,004 lebih kecil dari 0.05, sehingga bisa diduga bahwa antar variabel independen tidak terjadi persoalan multikolinearitas.

\subsection{Uji Heteroskedastisitas}

Kriteria pengujian adalah sebagai berikut:

1. Ho : tidak ada gejala heteroskedastisitas

2. Ha : ada gejala heteroskedastisitas

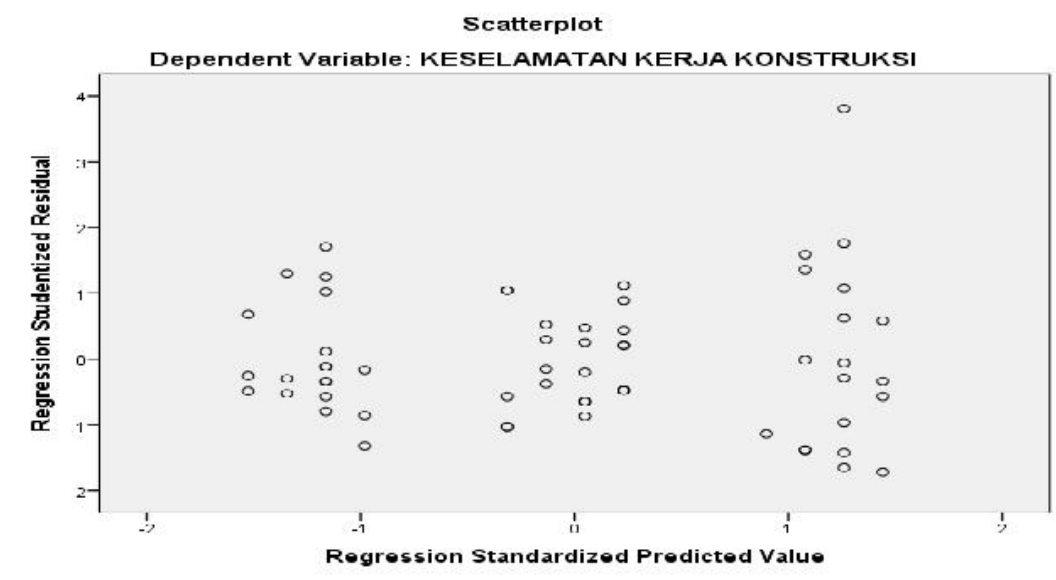

Gambar 1. Uji Heteroskedastisitas

Sumber : Hasil analisis Data SPSS 


\section{NAROTAMA JURNAL TEKNIK SIPIL \\ e-ISSN: 2460-3430}

VOLUME 3 NOMOR 1 JUNI 2019

Dari output di atas dapat diketahui bahwa titik-titik tidak membentuk pola yang jelas, dan titik-titik menyebar di atas dan di bawah angka 0 pada sumbu Y.

\subsection{Uji Autokorelasi}

Dan hasil pengujiannya dapat dilihat pada tabel 2.3 sebagai berikut ini :

Tabel 2.3 Hasil Uji Autokorelasi

\begin{tabular}{|c|c|c|c|c|c|c|c|c|c|c|}
\hline $\mathrm{M}$ & $R$ & $\mathrm{R}$ & Adjus & Std. & & Chang & Stat & istics & & Durbi \\
\hline 0 & & Squa & ted $\mathrm{R}$ & Error & $\mathrm{R}$ & $\mathrm{F}$ & Df & Df2 & Sig. & n- \\
\hline d & & re & Squar & of the & Squa & Chan & 1 & & F & Wats \\
\hline e & & & e & Estim & re & ge & & & Cha & on \\
\hline 1 & & & & ate & Cha & & & & nge & \\
\hline & & & & & nge & & & & & \\
\hline 1 & $249^{\mathrm{a}}$ & 062 &, 029 & 4,497 & 062 & 1,889 & 2 & 57 &, 161 & 1,023 \\
\hline
\end{tabular}

Sumber : Hasil analisis Data SPSS

nilai DW $(1,023)$ berada pada daerah antara dL dan dU.

\subsection{Regresi Linier Berganda}

Koefisien regresi Tingkat pendidikan $\left(\mathrm{X}_{2}\right)$ sebesar 1,378 yang artinya jika variabel independen lain nilainya tetap dan Tingkat pendidikan mengalami kenaikan 1\%, Keselamatan kerja (Y') akan mengalami peningkatan sebesar 1,378.

\subsection{Analisis Determinasi (R2)}

Variasi variabel independen yang digunakan dalam model menjelaskan 100\% variasi variabel dependen.

Tabel 2.4 Hasil Analisis Determinasi

\begin{tabular}{|l|l|l|l|l|l|l|l|l|l|l|}
\hline M & R & R & Adjus & Std. & \multicolumn{5}{|c|}{ Change Statistics } & Durbi \\
o & & Squa & ted R & Error & R & F & Df & Df2 & Sig. & n- \\
d & & re & Squar & of the & Squa & Chan & 1 & & F & Wats \\
e & & & e & $\begin{array}{l}\text { Estim } \\
\text { re }\end{array}$ & ge & & & Cha \\
on \\
ate
\end{tabular}

Sumber : Hasil analisis Data SPSS

Berdasarkan tabel di atas diperoleh angka $\mathrm{R}^{2}$ (R Square) sebesar 0,062 atau $(06,2 \%)$. 


\subsection{Uji Koefisien Regresi Secara Bersama-sama (Uji F)}

Hasil data anaalisis regresi dapat diketahui nilai $\mathrm{F}$ seperti pada tabel 2.12 berikut ini.

Tabel 2.5 Hasil Uji F

\begin{tabular}{|c|c|c|c|c|c|}
\hline Model & $\begin{array}{c}\text { Sum of } \\
\text { Squares }\end{array}$ & df & $\begin{array}{c}\text { Mean } \\
\text { Square }\end{array}$ & F & Sig. \\
\hline Regression & 76,377 & 2 & 38,188 & 1,889 &, $161^{\mathrm{b}}$ \\
Residual & 1152,607 & 57 & 20,221 & & \\
Total & 1228,983 & 59 & & & \\
\hline
\end{tabular}

Sumber : Hasil analisis Data SPSS

\subsection{Uji Koefisien Regresi Secara Parsial (Uji t)}

Uji koefisien regresi secara parsial ini digunakan untuk mengetahui apakah dalam model regresi variabel independen $\left(\mathrm{X}_{1}, \mathrm{X}_{2}, \ldots . . \mathrm{X}_{\mathrm{n}}\right)$ secara parsial berpengaruh signifikan terhadap variabel dependen $(\mathrm{Y})$.

Oleh karena nilai -t hitung $<$-t tabel $(-, 348 .<-1,671)$ maka Ho ditolak, artinya secara parsial berpengaruh signifikan antara perilaku tenaga kerja dengan keselamatan. Jadi dari kasus ini dapat disimpulkan bahwa secara parsial perilaku tenaga kerja berpengaruh terhadap keselamatan kerja.Pengujian koefisien regresi variabel tingkat pendidikan

Oleh karena nilai t hitung $<\mathrm{t}$ tabel $(1,886<1,671)$ maka Ho diterima, artinya secara parsial tidak ada pengaruh signifikan tingkat pendidikan dan keselamatan kerja. Jadi dari kasus ini dapat disimpulkan bahwa secara parsialtingkat pendidikan tidak berpengaruh positif terhadap keselamatan kerja.

\section{KESIMPULAN DAN SARAN}

1. Perilaku tenaga kerja

Perilaku tenaga kerja berpengaruh secara signifikan terhadap keselamatan kerja ( $\mathrm{R}$ $=0,668)$. Artinya secara parsial berpengaruh signifikan antara perilaku tenaga kerja dengan keselamatan.

2. Tingkat pendidikan tidak berpengaruh secara signifikan terhadap keselamatan kerja $(\mathrm{R}=0,062)$. Artinya secara parsial tidak ada pengaruh signifikan tingkat pendidikan dan keselamatan kerja. 


\section{DAFTAR PUSTAKA}

1. Algifari, (2000). "Analisis Regresi Teori, Kasus, dan Solusi”. Yogyakarta: BPFE.

2. Andi, dkk, (2005). "Model Persamaan Struktural Pengaruh Budaya Keselamatan".

3. Choirul, Mochammad, (2007). "Pengaruh Perilaku Tenaga Kerja Pada Proyek".

4. Suma'mur, (1985). "Keselamatan Kerja dan Pencegahan Kecelakaan”. Jakarta 